\title{
A Case Report Snake Bite Induced Acute Kidney Injury (AKI)
}

\author{
Abbas SK MD ${ }^{1, *}$, Noorjahan A', C. Bhargav Reddy', Mallikarjuna K2, Y Saivani² \\ 1Department of Pharmacy Practice, Santhiram College of Pharmacy, Nanadyal, Kurnool, Andhra Pradesh, INDIA. \\ ${ }^{2}$ Department of Nephrology, Santhiram Medical College, Nanadyal, Kurnool, Andhra Pradesh, INDIA.
}

\begin{abstract}
Acute Kidney Injury (AKI) complicating snake envenomation may pass for a "neglected" health condition in regions or parts of the world where its incidence is not as common. Now -a - days snake bite is a quite common in rural areas of India. Hence snake bite is considered as a important health hazard. Snake bite may also cause the mortality and morbidities of a person. Snake bite may produce the toxic effects to the multiple organs and may produce the injury mainly to the kidneys. Mostly snake bite produce the acute kidney injury and also risk for the many complications to the multiple organ dysfunctions and if it was not treated well leads to the mortality. Here we report a case of a person with snake bite which induce the acute kidney injury i,e acute tubular necrosis. He was treated with appropriate therapy according to the symptoms and also treated with haemodialysis without development of adverse effects and with supportive therapy.
\end{abstract}

Key words: Snake bite, acute kidney injury, Acute tubular necrosis, Supportive therapy, Maintained Haemodialysis (MHD).

\section{INTRODUCTION}

Globally snake bite is the common cause for the mortality and the morbidity. Snake bite is common in the tropical countries. Mostly 421000 envenoming and 20000 deaths occur every year due to the snake

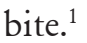

Most of the south-east Asian region snake bite is the common threat to the farmers and plantation workers which results in the thousands of the deaths., ${ }^{2,3}$ In India every year 30000 deaths occur due to the snake bite. ${ }^{4}$ Approximately the there are 2500 to 3000 species of snakes of present globally this may be some are venomous and non-venomous. In Southeast Asia there are two groups of a normal snakes glapidae represented by short permanently erect fangs. This group indicates the king cobras Snakes, kraits, coral snakes and the sea snakes. ${ }^{5,6}$ Viperdae are represented by the long fangs which are folded up opposite to the upper jaw. There are two subgroups pit vipers and vipers. Snake bite mainly direct effect the kidney mainly viperadae and sea snakes, colubridal group or responsible for the acute kidney injury and some of the viper bites also induce acute kidney injury.

\section{Pathophysiology of the snake venom} of induced acute kidney injury

Snake venom affect the kidney by many ways. These induces by aggressive immune response which leads to production of cytokine mediator's adhesion. This results the decrease of RBF which leads to the tubular necrosis and cortical necrosis and glomerular nephritis. Snake venom after the direct injury to the kidney through the following styles like haemolysis, myelonecrosis, intravascular coagulation this leads to the Tubular necrosisand cortical necrosis.
DOI: 10.5530/ijopp.15.1.11

Address for correspondence: Dr. Abbas SK MD, Department of Pharmacy Practice, Santhiram College of Pharmacy, Nanadyal, Kurnool, Andhra Pradesh, INDIA.

Email id: shaikmahammadabbas582@gmail.com

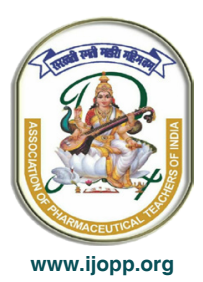




\section{Intrinsic acute kidney injury}

It is mainly occur due to the vascular damage, glomerular damage, acute tubular necrosis, acute intestinal nephritis. Ischemic changes, exotoxins and endotoxins mainly affect the tubules of nephrons which leads to the acute tubular necrosis. Exotoxins mainly nephrotoxins which are mainly present in the snake Venom. Snake envenomation produce the nephrotoxins which affect the kidney and thus may result into the tubular infiltration and the necrosis of the tubules in the Kidneys.

\section{Post renal acute kidney injury}

It occurs mainly due to the bladder outlet obstruction ureteral obstruction renal pelvis for tubular obstruction. ${ }^{8}$

\section{CASE DESCRIPTION}

A 35 years of male patient was admitted in the nephrology left ankle joint. He had bleeding at the wound site after the biting and pain followed by the inflammation of the left limb. After he was developed the decreased urine output, melena and vomiting since 2 days. He also found with gradual numbness with myalgia and hematuria since 2 days.

On examination he was conscious and oriented. He was found with pallor, jaundice, peripheral pulses and no history of bleeding from the gums His vitals are presented as BP:120/80 mm of Hg, PR:82, RR:20.

\section{LABORATORY INVESTIGATIONS}

\section{Complete Blood Picture}

\begin{tabular}{llll}
\hline SI.no & Parameter & Observe valve & Reference valve \\
\hline 1. & Neutrophils & $80 \%$ & $42-75 \%$ \\
2. & Esoinophils & $15 \%$ & $20-45 \%$ \\
3. & WBC & 13,000 cells & $4500-12000$ cells \\
4. & ESR & $90 \mathrm{~mm} / \mathrm{hr}$ & $0-10 \mathrm{~mm} / \mathrm{hr}$ \\
\hline
\end{tabular}

\section{LIVER FUNCTION TEST}

\begin{tabular}{cccc}
\hline SI.No & Parameter & Observed value & Reference value \\
\hline 1. & Total Bilirubin & $2 \mathrm{mg} / \mathrm{dl}$ & $0-1 \mathrm{mg} / \mathrm{dl}$ \\
2. & Direct Bilirubin & $2.5 \mathrm{mg} / \mathrm{dl}$ & $0-0.25 \mathrm{mg} / \mathrm{dl}$ \\
3. & SGOT & $80 \mathrm{IU} / \mathrm{L}$ & $0-37 \mathrm{IU} / \mathrm{L}$ \\
4. & SGPT & $200 \mathrm{IU} / \mathrm{L}$ & $0-65 \mathrm{IU} / \mathrm{L}$ \\
5. & ALP & $120 \mathrm{IU} / \mathrm{L}$ & $15-116 \mathrm{IU} / \mathrm{L}$ \\
6. & Total Proteins & $8 . \mathrm{mg} / \mathrm{dl}$ & $6-8 \mathrm{~g} / \mathrm{dl}$ \\
7. & Albumin & $5.8 \mathrm{mg} / \mathrm{dl}$ & $3.2-5.8 \mathrm{~g} / \mathrm{dl}$ \\
\hline
\end{tabular}

RENAL FUNCTION TESTS

\begin{tabular}{cccc}
\hline SI.No & Parameter & Observed value & $\begin{array}{c}\text { Reference } \\
\text { value }\end{array}$ \\
\hline 1. & Serum Creatinine & 2.9 & $0.5-1.4 \mathrm{mg} / \mathrm{dl}$ \\
2. & Serum Uric Acid & 8 & $3.5-7.0 \mathrm{mg} / \mathrm{dl}$ \\
3. & Serum Urea & 60 & $14-45 \mathrm{mg} / \mathrm{dl}$ \\
\hline
\end{tabular}

\section{SERUM ELACROLYTES}

\begin{tabular}{cccc}
\hline SI. No & Parameter & Observed value & Reference value \\
\hline 1. & Sodium & 140 & $136-145 \mathrm{mmol} / \mathrm{l}$ \\
2. & Potassium & 2.8 & $3.5-5.1 \mathrm{mmol} / \mathrm{l}$ \\
3. & Chloride & 104 & $96-104 \mathrm{mmol} / \mathrm{l}$ \\
\hline
\end{tabular}

\section{COMPLETE URINRE EXAMINATION}

\begin{tabular}{cccc}
\hline SI.No & Parameter & $\begin{array}{c}\text { Observed } \\
\text { value }\end{array}$ & Reference value \\
\hline 1. & Colour & YELLOWISH & \\
2. & Albumin & $4++++$ & 02 \\
3. & Epithelial Cells & $10-12$ CELLS & $2-3 \mathrm{hpf}$ \\
4. & RBC & $8-9$ & $0-3 \mathrm{hpf}$ \\
5. & Pus Cells & $12-14$ & $1-3 \mathrm{hpf}$ \\
\hline
\end{tabular}

On examination of the patient blood sample liver function tests are seen at the normal which includes the increases SGOT and after the Rx the values of the SGOT is normal. RFTs are normal which includes the abnormal increase serum creatinine and serum urea.

\section{BIOPSY OF THE KIDNEY}

\section{Microscopic Examination}

Serial sections studied show a core of renal cortex with upto 13 glomeruli.

1. The glomeruli appear normal with no increase in cellularity/ crescents/ necrosis.

2. Tubules show extensive injury in the form of luminal dilatation, loss of brush border and flattening of lining epithelium. Many tubules show granular casts and few show red cell casts.

3. Interstitium and vessels appear normal.

4. Immunofluorescence study shows no significant immune deposits.

Indian Journal of Pharmacy Practice, Vol 15, Issue 1, Jan-Mar, 2022 


\section{IMPRESSION}

Kidney (needle) biopsy shows features suggestive of Acute tubular necrosis.

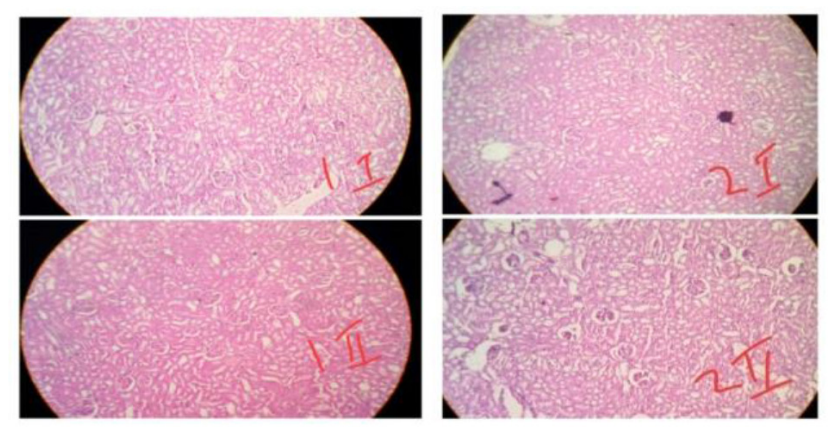

Normal tissues of tubules

Acute tubular necrosis

\section{TREATMEMT}

\begin{tabular}{|c|c|c|c|c|c|}
\hline $\begin{array}{l}\text { O } \\
\text { मं }\end{array}$ & 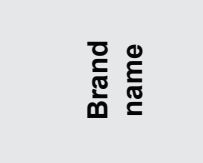 & 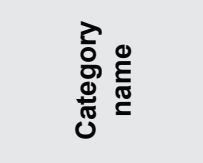 & \& & 운 & 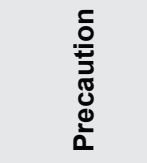 \\
\hline 1. & INJ. Zostum & Anti-biotic & $1.5 \mathrm{gm}$ & $\mathrm{BD}$ & \\
\hline 2. & INJ. Vitamin K & Multi Vitamin & 10 mg & $\mathrm{BD}$ & \\
\hline 3. & INJ. Pantop & Anta Acid & $40 \mathrm{mg}$ & $\mathrm{BD}$ & \\
\hline 4. & INJ. Metrogyl & Anti Protozoal & $200 \mathrm{mg}$ & $\mathrm{BD}$ & \\
\hline 5. & T. Auxipro & Probiotic & $1 \mathrm{TAB}$ & $\mathrm{BD}$ & \\
\hline 6. & SYP. Lactulose & Laxative & & TID & $\begin{array}{l}\text { Shake wel } \\
\text { before use }\end{array}$ \\
\hline 7. & SYP. Ambroxal & Brochodialator & & $\mathrm{BD}$ & $\begin{array}{l}\text { Shake well } \\
\text { before use }\end{array}$ \\
\hline 8. & SYP. Potchlor & $\begin{array}{l}\text { Potassium } \\
\text { Supllement }\end{array}$ & & TID & \\
\hline
\end{tabular}

\section{DISCUSSION}

Snake bite is an acute life threatening time limiting medical emergency. It is a preventable public health hazard often faced by rural population in tropical and subtropical countries. Most of the Literature is focused on snakebite morbidity and mortality. Snake bite and envenoming leads to more than 20000 deaths per year. The incidence of complication is directly proportional to duration of venom in the blood prior to neutralization to anti snake venom. Complications of snake bite includes acute injury RBF which leads to tubular necrosis, cortical necrosis glomerul nephritis. Anti-snake venom is the only effective specific treatment of snake bite envenoming. In this case report 35 years old male patient was admitted in nephrology by snake bite on his left ankle joint local examination of patient's ankle joint it was observed the inflammation on the left Limb and developed decreased urine output, malea and vomiting for two days. Vitals for presented by BP 120/80 mm of HG, PR 82 RR 20. When patient gone through laboratory examination that shows abnormal increase in neutrophils decrease of lymphocytes, esinophils. Liver function examination shows abnormal increase in SGOT and normal SGPT. Renal function examination of patient shows abnormal increase in serum creatinine serum urea. Urine sample of patient was found in pale yellow and presence of albumin in urine. Microscopic examination of kidney shows no increase in cellularity/ crescents/ necrosis in glomeruli. Cube you show extensive injury in the form of luminal dilation, brush border, flattening of lining epithelium. Interstitium and vessels appear normal. Immunofluorescence study shows no significant immune deposits. Patient was treated with zostrum antibiotic injection Vitamin $\mathrm{K}$ injection, antacid injection Metrogyl antiprotozoal, Emset antiemetic injection. And the patient was treated with Auxipro tablet which is a probiotic. Lactulose and ambroxal syrup. Patient was also undergone haemodialysis.

\section{CONCLUSION}

Snakebite leading to multiple complications including renal failure and death is a major health issue in tropical countries. Acute kidney injury is a severe complication of snake envenoming. Clinical conditions which occur due to acute kidney injury are acute tubular necrosis, cortical necrosis, glomerular nephritis. Patient caught by the snake bite has complications like bleeding at the wound site followed by inflammation of the left limb. He also suffered with the decreased urine output, malena, icterus, vomiting for 2 days also found with gradual numbness and hematuria for two days. Antisnake venom is the only effective specific treatment of snake bite envenoming. The patient is treated according to clinical condition which include the antibiotics, antiprotozoals and antiemetic and with probiotics to reduce the clinical complications of snake bite. The patient was undergone heamodialysis for normal urination.

\section{ACKNOWLEDGEMENT}

We humbly submit this work to the almighty. We wish to express my sincere gratitude and thanks to our beloved Principal Dr. C. Madhusudhana Chetty M. Pharm, Ph.D., MBA, for his encouragement, helpful suggestions. We extend our heartfelt thanks to Prof. Dr. R.E. Ugandar, M. Pharm, PhD, Head of the Department, Department of Pharmacy Practice Thanks 
to our Hospital PreceptorDr. Y. Saivani MBBS., MD., DM. Department of Nephrology Santhiram Medical College and General Hospital, Nandyal, A.P for his constant enduring support

\section{CONFLICT OF INTEREST}

The authors declare that there is no conflict of interest.

\section{Informed Consent}

The patient whose case is described in the case report has provided written consent for the publication of this manuscript and any accessory images.

\section{ABBREVIATIONS}

AKI: acute kidney injury A; ATN: Acute tubular necrosis; ASV: anti snake venome; SGOT: serum glutamic oxaloacetic transaminase; SGPT: serum glutamic pyruvic transaminase; CUE: Complete urine examination; RFT: renal function test; LFT: liver function test; BP: blood pressure; PR: pulse rate; RR: respiratory rate.

\section{REFERENCES}

1. Kasturiratne A, Wickremasinghe AR, De Silva N, Gunawardena NK, Pathmeswaran A, Premaratna $\mathrm{R}$, et al. The global burden of snakebite: A literature analysis and modelling based on regional estimates of envenoming and deaths. PLOS Med. 2008 Nov 4;5(11):e218. doi: 10.1371/journal. pmed.0050218, PMID 18986210.

2. Warrell DA. WHO/SEARO Guidelines for the clinical management of snakebite in the Southeast Asian Region. Se Asian J Trop Pub HIth. 1999;30:1-85.

3. Warrell DA. Injuries, envenoming, poisoning, and allergic reactions caused by animal. In: Warrell DA, Cox TN, Firth JD, Benz J Jr, editors. Oxford textbook of medicine. Oxford: Oxford University Press; 2003;923-45.

4. Al-Homrany MA. Acute renal failure due to snake-bite: Clinical aspects. Saudi J Kidney Dis Transpl. 1998;9(3):285-9. PMID 18408301.

5. Simpson ID, Norris RL. Snakes of medical importance in India: Is the concept of the "big 4" still relevant and useful? Wilderness Environ Med. 2007;18(1):2-9. doi: 10.1580/06-weme-co-023r1.1, PMID 17447706.

6. Saini RK, Sharma S, Singh S, Pathania NS. Snake bite poisoning: A preliminary report. J Assoc Physicians India. 1984;32(2):195-7. PMID 6611333.

7. Mittal BV. Acute renal failure following poisonous snake bite. J Postgrad Med. 1994;40(3):123-6. PMID 8699376.

8. Reid HA, Theakston RD. The management of snake bite. Bull World Health Organ. 1983;61(6):885-95. PMID 6609008. 